\title{
Proceedings
}

of the

PREHISTORIC SOCIETY

for 1944

(New Series, Vol. X)

\author{
Edited by J. G. D. CLARK, M.A., Ph.D., F.S.A. \\ University Museum of Archaeology and Ethnology, Downing Street, Cambridge
}

1. Report on excavations carried out in the cave known as 'Bosumpra,' at Abetifi,

Page

Kwahu, Gold Coast Colony. By C. T. Shaw -

Note :

Preliminary report on a microlithic industry at Rop rock shelter, Northern Nigeria

(Bernard Fagg)

The Annual Subscription for Membership of the Society, entitling members to the Proceedings as well as attendance at meetings, is Fifteen Shillings.

Apply to C. W. Phillips, M.A., F.S.A., Honorary Secretary, Selwyn College, Cambridge.

London Agents : H. K. Lewis \& Co. Ltd., 136, Gower Street, London, W.C.I. 


\section{THE PREHISTORIC SOCIETY}

The Society was originally founded in 1908 as the Prehistoric Society of East Anglia. The scope of the Society's work gradually expanded until, at the Annual General Meeting in 1935 , the local designation was dropped from its title.

\section{THE PROCEEDINGS}

The series of Proceedings published by the Society under its earlier name was terminated by volume VII, part III, issued in January, 1935.

The New Series began with Vol. I, issued in December, 1935.

Back numbers of the Proceedings can be supplied, with certain exceptions, on application to the Honorary Secretary, Selwyn College, Cambridge.

\section{BINDING-CASES FOR PROCEEDINGS}

Official buckram binding cases for annual volumes of the Proceedings can be obtained (exclusively) from John Bellows, Ltd., Eastgate, Gloucester, England : price 4/- plus postage binding Complete $7 /$ - plus postage. Members desiring to have their Proceedings bound should send them to John Bellows, Ltd. Remittance must accompany the order.

\section{CONTRIBUTIONS TO THE PROCEEDINGS}

Original notes and papers, and books and shorter articles for notice or review, should all be sent to the Honorary Editor at the University Museum of Archaeology and Ethnology. Downing Street, Cambridge, or 42. Barton Road, Cambridge.

\section{MEMBERSHIP AND SUBSCRIPTION}

Admission to membership of the Society is by election and is open to individuals and to institutions and libraries. An entrance fee of $10 \%$ is payable on election. Further particulars can be obtained from Mr C. W. Phillips, M.A., F.S.A., Honorary Secretary, Selwyn College, Cambridge.

The annual subscription of $15 /-$, which entitles members to the Proceedings (price to non-members $\mathrm{El}$ ), is payable in advance on January Ist. Cheques, or preferably banker's orders. should be sent to the Honorary Treasurer, Mr E. M. M. Alexander, c/o The Department of British and Mediaeval Antiquities, British Museum. London, W.C. I. 


\title{
Proceedings of the
}

\section{PREHISTORIC SOCIETY for 1944}

New Series, Vol. $X$

(Proceedings of the Prehistoric Society of East Anglia, 1908-1935)

Edited by J. G. D. CLARK, M.A., Ph.D., F.S.A.

\begin{abstract}
The Proceedings, consisting of an annual volume (issued during 1936-9 in two parts), are distributed freely to members of the Society. Individual parts or volumes can be purchased by non-members on application to the Honorary

Secretary, Mr C. W. Phillips, M.A., F.S.A., Selwyn College, Cambridge.

Price : One Pound or Five Dollars (Ten Shillings or Two Dollars and Fifty Cents each part)

London Agents :

H. K. LEWIS \& CO., LTD., 136 Gower Street LONDON, W.C. I
\end{abstract}

THE UNIVERSITY MUSEUM OF ARCHAEOLOGY AND ETHNOLOGY

DOWNING STREET, CAMBRIDGE 


\title{
CONTENTS
}

\section{PROCEEDINGS OF THE PREHISTORIC SOCIETY:}

\author{
New Series, Vol. $X$
}

Members of the Council for 1944 Page

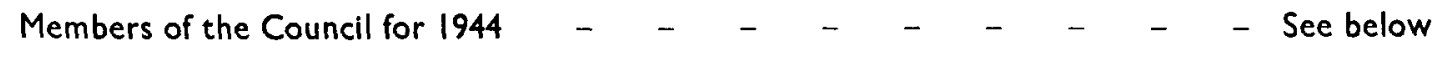

I. Report on excavations carried out in the cave known as 'Bosumpra,' at Abetifi,

Kwahu, Gold Coast Colony. By C. T. Shaw - $-{ }_{-}-{ }_{-}-1$

Notes :

Preliminary report on a microlithic industry at Rop rock shelter, Northern Nigeria

(Bernard Fagg) - - - - - $-4-68$

Nos.
I. 'Bosumpra' Cave, Abetifi, Gold Coast - PLATES
II. Grinding grooves, Akwatia, Gold Coast - -
III, IV. Rop rock-shelter, Northern Nigeria - -

MEMBERS OF THE COUNCIL FOR 1944

Officers

President: Miss G. Caton Thompson, F.B.A., F.S.A.

Hon. Secretary: C. W. Phillips, M.A., F.S.A. Hon. Treasurer: E. M. M. Alexander, F.S.A. Hon. Editor : J. G. D. Clark, M.A., Ph.D., F.S.A.

A. W. G. Lowther, F.S.A.

T. T. Paterson, M.A., F.G.S.

W. J. Varley, M.A., F.S.A.

Mrs E. M. Clifford, F.S.A.

J. Wilfrid Jackson, D.Sc., F.G.S.
R. S. Newall, M.A., F.S.A.

Mrs M. A. Cotton

T. Wake

K. P. Oakley, B.Sc., Ph.D., F.G.S.

Miss M. C. Sloane Stanley 